\title{
Comparative Pharmacokinetics of Metronidazole in Camels, Sheep and Goats
}

\author{
B.H. ALI *, B.G. CHARLES $\dagger$, M. AL-YOUSIF, A.K. BASHIR
}

Department of Veterinary Medicine, King Saud University, Al-Gaseem Branch, Saudi Arabia, Desert and Marine Environment Research Center, United Arab Emirates University, Al-Ain, United Arab Emirates, $\dagger$ School of Pharmacy, The University of Queensland, QLD 4072, Australia

Received January 3, 2002
Accepted November 18, 2002

\section{Abstract}

Ali, B. H., B. G. Charles, M. Al-Yousif, A. K. Bashir: Comparative Pharmacokinetics of Metronidazole in Camels, Sheep and Goats. Acta Vet Brno 2002, 71: 49-53.

The pharmacokinetics of metronidazole was determined after a single intramuscular (i.m.) dose of $30 \mathrm{mg} \cdot \mathrm{kg}^{-1}$-body weight in five camels, sheep and goats. Marked differences were found between the three species in some of the kinetic parameters. For example, the elimination half-lives $\left(\mathrm{t}_{1 / 2} ; \mathrm{h}\right)$ in camels, sheep and goats were 10.0, 6.21 and 5.87, respectively. The drug maximum concentrations in plasma, $C_{\max }\left(\mathrm{mg} \cdot \mathrm{ml}^{-1}\right)$, were $28.3,54.6$ and 54.4 in camels, sheep and goats, respectively. The time to reach $\mathrm{C}_{\text {max }}, \mathrm{t}_{\mathrm{max}}(\mathrm{h})$, were 5,4 and 2 in camels, sheep and goats, respectively. The mean residence times (MRT; h) in camels, sheep and goats were 16.7, 10.8 and 8.64 , respectively. In the light of the present kinetic data and known microbial sensitivities of metronidazole, we recommend an i.m. dose of $15 \mathrm{mg} \cdot \mathrm{kg}^{-1}$ in camels and $10 \mathrm{mg} \cdot \mathrm{kg}^{-1}$ in sheep and goats, every $12 \mathrm{~h}$.

Ruminants, kinetics, metronidazole, antiprotozoals, antibacterials

Metronidazole (2-methyl-5-nitroimidazole-1-ethanol) is a synthetic bactericidal and antiprotozoal agent that is used to treat certain urogenital diseases such as trichomoniasis, giardiasis, Balantidium coli, and intestinal and extraintestinal amoebiasis. It is also effective against bacterial anaerobes. The drug is also considered a reliable marker or probe for studying liver function in vivo (Muscar et al. 1995). The pharmacokinetics of this drug has been reported previously following intravenous (i.v.), oral or rectal administration to humans (Jensen and Gugler 1983; Loft et al. 1986), horses (Baggot et al. 1988; Specht et al. 1992), calves (Bhavsar and Malik 1994), dogs (Neff-Davis et al. 1981), birds (Cybulski et al. 1996) and rats (Tu et al. 1990).

Intramuscular (i.m.) administration of drugs to animals, particularly larger grazing animals, may often be more convenient than by other routes particularly in chronic treatment. There have been no pharmacokinetic data reported for i.m. administration of metronidazole, and this was the purpose of the current study in which a single $30 \mathrm{mg} \cdot \mathrm{kg}^{-1}$ i.m. dose was administered to camels, sheep and goats. These species are susceptible to the bacterial and protozoal infections treatable with metronidazole.

\section{Materials and Methods}

Animals and procedures

The protocol received prior approval from the Animal Research Ethics Committee of the Desert and Marine Environment Research Center. Animals used in this study were healthy, male Dromedary camels (Camelus dromedarius) aged 3-4 years and weighing 270-350 kg, Desert sheep (Ovis aries) aged 2-3 years and weighing $27-33 \mathrm{~kg}$ and Nubian goats (Capra hircus) aged 2-3 years and weighing 22-27 kg ( $\mathrm{n}=5$ of each species). When used, they have been housed for at least two years in shaded pens at the University farm, where they were given hay and water ad libitum, and the diet was supplemented with pelleted concentrates and mineral blocks. The animals were given a single i.m. dose of metronidazole (Torgyl-Forte, Rhone-Merieux, Harlow, Essex, U.K.) into the lower third region of the neck muscles. Blood ( $5 \mathrm{ml}$ per sample) was collected into heparinized tubes just before, then after metronidazole administration at the following times: 10, 20, 40, 60, 90, 120, 240, 300, 360, 420, 
480 and $600 \mathrm{~min}$. Blood was centrifuged at $900 \mathrm{~g}$ for $10 \mathrm{~min}$ at $5^{\circ} \mathrm{C}$, and the harvested plasma was immediately stored at $-70{ }^{\circ} \mathrm{C}$ until analysed.

Drug analysis

Plasma samples were assayed for metronidazole concentration using a high performance liquid chromatographic (HPLC) method (Neff-Davis et al. 1981) with minor modifications. Briefly, reverse-phase separations were developed (Whatman Partisil 10 column, ODS-2 bonded packing, $10 \mu \mathrm{m}$ particles, $4.6 \mathrm{~mm}$ i.d. $\times 250 \mathrm{~mm}$ ) using a mobile phase of $65 \% \mathrm{v} / \mathrm{v}$ methanol in $0.01 \mathrm{M}$ acetate buffer, pumped at $63 \mathrm{ml} \cdot \mathrm{h}^{-1}$. Detection was at $254 \mathrm{~nm}$. Caffeine was employed as the internal standard to minimise errors from volume changes. The retention times for metronidazole and caffeine were $3.7 \mathrm{~min}$ and $5.4 \mathrm{~min}$, respectively. Recovery of metronidazole following extraction from camel, sheep and goat plasma was $90.9 \pm 11.8 \%, 88.5 \pm 7.1 \%$ and $68.4 \pm 12.8 \%(\mathrm{n}=6$ experiments), respectively. Calibrations for each species were prepared by supplementing drug-free plasma with metronidazole. Duplicate analyses were performed. The minimum quantifiable concentration of the assay was $0.05 \mathrm{mg} \cdot \mathrm{l}^{-1}$. Intra- and inter-assay coefficients of variation were less than $10 \%$ over the working concentration range of $0.1-2.5 \mathrm{mg} \cdot \mathrm{l}^{-1}$.

Kinetic analysis

The maximum plasma concentration $\left(\mathrm{C}_{\max }\right)$ and the time $\left(\mathrm{t}_{\max }\right)$ to reach the $\mathrm{C}_{\max }$ were obtained by inspection of the raw data. The elimination rate constant $\left(\mathrm{K}_{\mathrm{el}}\right)$ was represented by the slope of the terminal phase following leastsquares fitting of the post-peak plasma concentration-time data, from which was calculated the terminal half-life $\left(\mathrm{t}_{1 / 2}=0.693 / \mathrm{K}\right)$. Areas under the metronidazole plasma concentration-time curve extrapolated to infinite time $\left(\mathrm{AUC}_{0-\infty}\right)$ were calculated using log-trapezoidal integration. Calculation of the pharmacokinetic parameters was performed using a non-compartmental approach (Rowland and Tozer 1995a); the systemic clearance, $(\mathrm{Cl} / \mathrm{F})$, and the apparent steady-state volume of distribution $\left(\mathrm{V}_{\mathrm{ss}} / \mathrm{F}\right)$, both corrected for fraction $(\mathrm{F})$ of the absorbed dose, were calculated as follows:

$$
\begin{aligned}
& \mathrm{Cl} / \mathrm{F}=\mathrm{D} / \mathrm{AUC}_{0-\infty} \\
& \mathrm{MRT}=\mathrm{AUMC}_{0-\infty} / \mathrm{AUC}_{0-\infty} \\
& \mathrm{V}_{\mathrm{ss}} / \mathrm{F}=\mathrm{Cl} / \mathrm{F} \cdot \mathrm{MRT}
\end{aligned}
$$

where $\mathrm{D}$ is the metronidazole dose, $\mathrm{AUMC}_{0-}$ is the area under the first moment metronidazole plasma concentration-time curve, extrapolated to infinite time, and MRT is the mean residence time of metronidazole in the body from the time of administration to its elimination.

Statistics

Statistical hypothesis testing on $t_{1 / 2}$ values were performed using the MINITAB for Windows package (release 12.1, Minitab Inc., State College, PA, USA). Pharmacokinetic parameter values were expressed as the mean \pm SD, except $t_{\max }$, which was recorded as the median. Testing for normality was conducted using the Anderson-Darling statistic (D' Agostino and Stephens 1986). Species differences in $t_{1 / 2}$ were compared by means of one-way analysis of variance. Posthoc, pairwise comparisons of mean $t_{1 / 2}$ values (camel:goat, camel:sheep, sheep:goat) were analyzed by Duncan's multiple range test (Dunnett and Goldsmith 1994). The significance level (P) was set to 0.05 in all statistical analyses.

\section{Results}

All animals tolerated metronidazole well by the i.m. route. Semilogarithmic plasma concentration-time plots are shown in Fig 1. Plasma concentrations were quantifiable within $10 \mathrm{~min}$ of administration in each species. The pharmacokinetic parameters are summarised in Table 1 . The $\mathrm{C}_{\max }(\mathrm{mg} / \mathrm{ml})$ and $\mathrm{t}_{\max }(\mathrm{h})$ of the drug in camels $(28.3$ and $5)$, were markedly different from that in sheep (54.6 and 4) and goats (54.4 and 2). The $t_{1 / 2}$ values were drawn from a distribution which did not deviate significantly from normal (Anderson-

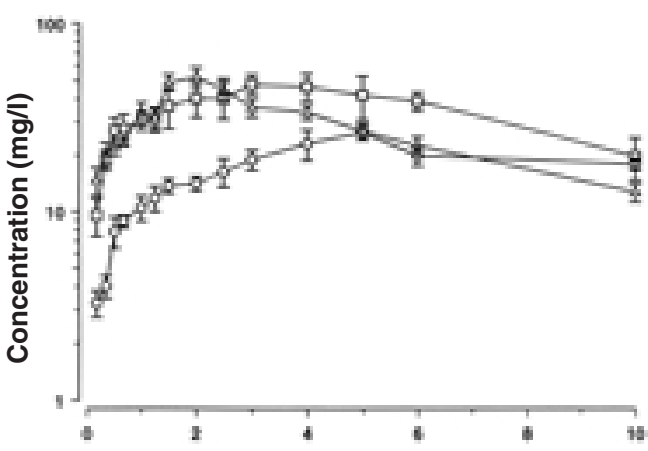

Fig 1. Semilogarithmic plots of plasma concentration of metronidazole versus time in $(\bigcirc)$ camels, $(\square)$ sheep and $(\triangle)$ goats after $30 \mathrm{mg} \cdot \mathrm{kg}^{-1}$ i.m. administration. Each point depicts mean \pm SD data from 5 animals. 
Table 1

Mean ( \pm SD) pharmacokinetic values of metronidazole following i.m. administration $\left(30 \mathrm{mg}^{\mathrm{kg}} \mathrm{kg}^{-1}\right)$ to camels, sheep and goats

\begin{tabular}{|c|c|c|c|c|c|c|c|}
\hline Animal & $\begin{array}{c}\mathrm{C}_{\max } \\
\left(\mathrm{mg} \cdot \mathrm{L}^{-1}\right)\end{array}$ & $\begin{array}{l}\mathrm{t}_{\max } \\
(\mathrm{h})\end{array}$ & $\begin{array}{c}\text { AUC0- } \\
\left(\mathrm{mg} \cdot \mathrm{L} \cdot \mathrm{h}^{-1}\right)\end{array}$ & $\begin{array}{c}\mathrm{Cl} / \mathrm{F} \\
\left(\mathrm{L} \cdot \mathrm{h} \cdot \mathrm{kg}^{-1}\right)\end{array}$ & 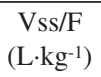 & $\begin{array}{c}\text { MRT } \\
\text { (h) }\end{array}$ & $\begin{array}{l}t_{1 / 2} \\
\text { (h) }\end{array}$ \\
\hline Camel & $\begin{array}{c}28.3 \\
(4.76)\end{array}$ & $5.0 *$ & $\begin{array}{c}446 \\
(260)\end{array}$ & $\begin{array}{c}0.103 \\
(0.0879)\end{array}$ & $\begin{array}{c}1.10 \\
(0.133)\end{array}$ & $\begin{array}{c}16.7 \\
(10.3)\end{array}$ & $\begin{array}{c}10.0 \\
(7.65)\end{array}$ \\
\hline Sheep & $\begin{array}{c}54.6 \\
(15.7)\end{array}$ & $4.0 *$ & $\begin{array}{c}555 \\
(227)\end{array}$ & $\begin{array}{c}0.0618 \\
(0.0252)\end{array}$ & $\begin{array}{c}0.571 \\
(0.265)\end{array}$ & $\begin{array}{c}10.8 \\
(6.92)\end{array}$ & $\begin{array}{c}6.21 \\
(4.93)\end{array}$ \\
\hline Goat & $\begin{array}{c}54.4 \\
(12.7)\end{array}$ & $2.0 *$ & $\begin{array}{c}377 \\
(92.2)\end{array}$ & $\begin{array}{c}0.0835 \\
(0.0209)\end{array}$ & $\begin{array}{c}0.683 \\
(0.144)\end{array}$ & $\begin{array}{c}8.64 \\
(3.27)\end{array}$ & $\begin{array}{c}5.87 \\
(2.79)\end{array}$ \\
\hline
\end{tabular}

*Median

$\mathrm{N}=5$ in each species.

Darling A-squared value $=0.463, P>0.05$ ). Although there were no statistically significant differences $(P>0.05)$ among the mean $\mathrm{T}_{1 / 2}$ values for the 3 species, or between-species pairs of means $(P>0.05)$, there appeared to be noticeable differences in this parameter among the three species (camels: $10.0 \mathrm{~h}$; sheep: $6.21 \mathrm{~h}$; and goats $5.87 \mathrm{~h}$ ). Comparison of the Twith previously reported values in other animals and humans is shown in Table 2.

Table 2

Mean $( \pm \mathrm{SD}) \mathrm{T}_{1 / 2}$ values of metronidazole in different species

\begin{tabular}{|l|c|c|c|c|c|}
\hline Species & $\mathrm{n}$ & $\begin{array}{c}\text { Dose } \\
\left(\mathrm{mg} \cdot \mathrm{kg}^{-1}\right)\end{array}$ & $\begin{array}{c}\text { Route } \\
(\mathrm{h})\end{array}$ & $\mathrm{t}_{1 / 2}$ & Reference \\
\hline Hen & 9 & 30 & i.v. & $4.2(0.5)$ & Cybulski et al. 1996 \\
Calf & 8 & 20 & i.v. & $1.9(0.1)$ & Bhavsar and Malik 1994 \\
Rat & 30 & 25 & i.v. & $5.0 *$ & Tu et al. 1990 \\
Dog & 8 & 44 & i.v. & $4.5(0.9)$ & Neff-Davis et al. 1981 \\
Horse & 6 & 10 & i.v. & $3.9(0.5)$ & Baggot et al. 1988 \\
Human & 7 & 6 & i.v. & $8.3(0.4)$ & Jensen and Gugler 1983 \\
Camel & 5 & 30 & i.m & $10.0(7.7)$ & This study \\
Sheep & 5 & 30 & i.m. & $6.2(4.9)$ & This study \\
Goat & 5 & 30 & i.m. & $5.9(2.8)$ & This study \\
\hline
\end{tabular}

*SD not reported

\section{Discussion}

No previous data existed for the i.m. administration of metronidazole in animals. A noncompartmental analysis was used because of the erratic absorption of metronidazole from the i.m. site into the bloodstream. In camels, the overall rate of absorption from the muscles into the main circulation appeared to be less than in sheep and goats, as seen in the plasma concentration-time plots. In one of our recent studies (Ali et al. 1998) less than threequarters of the i.m. dose of furosemide was systemically absorbed in camels from a site anatomically similar to that used in the present study. Low and variable i.m. absorption is well known from many human studies on other drugs, and is considered to be due mostly to variability in regional blood flow (Gibaldi 1991).

There was considerable inter-individual variability in all pharmacokinetic values, for each species. Since only single-dose i.m metronidazole was given, hypothesis testing for species differences in pharmacokinetics was limited because of the possible confounding 
influence of the unknown systemic i.m. bioavailability. However, assuming that $\mathrm{V}_{\mathrm{ss}}$ and $\mathrm{Cl}$ were independent of the dose, the $t_{1 / 2}$ in camels, sheep and goats can be compared. The mean $\mathrm{t}$ did not differ significantly among the three species, although the small number of animals per group $(n=5)$ coupled with appreciable variability (pooled $\mathrm{SD}=5.5 \mathrm{~h}$ ) resulted in a statistical power of only $17 \%$. Further sample size calculations indicated that 29 animals of each species would be required to show a significant difference in $\mathrm{t}$ with an $80 \%$ power. Nonetheless, marked differences in the kinetic parameters among the three species indicated that the camels absorbed and eliminated metronidazole at a rate slower than that seen in sheep or goats. This is in line with previous studies using other probe drugs such as antipyrine.

In humans, metronidazole is converted to several metabolites (Stambaugh et al. 1968; Loft et al. 1986), and some of these may be active. However, in the present study we did not (for technical reasons) measure plasma concentrations of metabolites in treated animals. Kinetic differences between the three species may not be limited to the parent drug but may also include the metabolic pathways and the relative amounts of the different metabolites of the parent drug. For example, differences between camels and goats in the metabolism of paracetamol (acetaminophen) were reported by some of us previously (Ali et al. 1996).

Dose recommendations for the use of i.m. metronidazole in camels, sheep and goats can be made in light of the present pharmacokinetic data, and known antimicrobial sensitivities. For metronidazole, the minimum inhibitory concentration for $90 \%$ of clinical isolates tested $\left(\mathrm{MIC}_{90}\right)$ was $2 \mathrm{mg} \cdot \mathrm{l}^{-1}$ for most Gram-negative anaerobes such as Bacteroides species, and $4 \mathrm{mg} \cdot \mathrm{l}^{-1}$ for Gram-positive anaerobic bacteria such as Clostridium species (Prescott and Bagg ot 1993). Therefore, using standard pharmacokinetic formulae for the accumulation of drug concentrations to steady-state (Rowland and Tozer 1995b), we determined that average concentrations, peak concentrations and trough concentrations of $12 \mathrm{mg} \cdot \mathrm{l}^{-1}, 22$ $\mathrm{mg} \cdot \mathrm{l}^{-1}$, and $6 \mathrm{mg} \cdot \mathrm{l}^{-1}$, respectively, should be obtained in plasma at steady-state during 12 hourly i.m. administration of $15 \mathrm{mg} \cdot \mathrm{kg}^{-1}$ in camels, and $10 \mathrm{mg} \cdot \mathrm{kg}^{-1}$ in sheep and goats.

Further experiments to study the kinetics and bioavailability of metronidazole given by different routes and using a larger number of animals than has been used here, are warranted.

\section{Srovnání farmakokinetiky metronidazolu u velbloudů, ovcí a koz}

Farmakokinetika metronidazolu byla stanovena po jediném intramuskulárním podání dávky $30 \mathrm{mg} \cdot \mathrm{kg}^{-1}$ ž. h. skupinám velbloudů, ovcí a koz, čítajícím po pěti jedincích. Mezi těmito třemi druhy byly nalezeny značné rozdíly některých kinetických ukazatelů, např. poločas vyloučení $\left(\mathrm{t}_{1 / 2} \mathrm{~h}\right)$ u velbloudů, ovcí a koz byl 10,0, 6,21 a 5, 87 hodin. Maximální koncentrace léku v krevní plazmě, $\mathrm{C}_{\max }\left(\mathrm{mg} \cdot \mathrm{ml}^{-1}\right)$ byly 28,3, 54,6 a 54,4 h u velbloudů, ovcí a koz. Čas potřebný k dosažení maximální koncentrace léku byl 5, 4 a 2 h. Na základě kinetických údajů a známé mikrobiální sensitivity metronidazolu autoři doporučují i.m. dávky $15 \mathrm{mg} \cdot \mathrm{kg}^{-1} \mathrm{u}$ velbloudů a dávku $10 \mathrm{mg} \cdot \mathrm{kg}^{-1} \mathrm{u}$ ovcí a koz každých 12 hodin.

Acknowledgements

The authors thank Dr. G. Hadrami and the staff of the United Arab Emirates University Farm for their help with the camels, Professor P. Lees for obtaining metronidazole, and Mr. M. Al Mufti for technical assistance.

\section{References}

ALI, BH, CHENG, Z, ALHADRAMI G, BASHIR, AK, McKELLAR, QA 1996: Comparative pharmacokinetics of paracetamol (acetaminophen) and its sulphate and glucuronide metabolites in desert camels and goats. J Vet Pharmac Therap 19: 238-244

ALI, BH, WONG, Y-C, ALHADRAMI G, CHARLES, BG, BASHIR, AK 1998: Plasma pharmacokinetics of intravenous and intramuscular furosemide in the camel (Camelus dromedarius). Res Vet Sci 64: 69-72

BAGGOT, JD, WILSON, WD, HIETALA, S 1988: Clinical pharmacokinetics of metronidazole in horses. J Vet Pharmac Therap 11: 417-420 
BHAVSAR, SK, MALIK, JK 1994: Pharmacokinetics of metronidazole in calves. Brit Vet J 150: 389-393

CYBULSKI, W, LARSSON, P, TJAELVE, H, KOWALSKA- PYLKA, H, SYLLA, M SEMENIUK, S.1996: Disposition of metronidazole in hens (Gallus gallus) and quails (Coturnix coturnix japonica): pharmacokinetics and whole-body autoradiography. J Vet Pharmacol Therap 19: 352-358

D'AGOSTINO, RB, STEPHENS, MA 1986: Tests for the normal distribution. In Goodness-of-Fit Techniques, Marcel Dekker, Inc., New York, pp. 372-373

GIBALDI, M 1991: Nonoral medication. In Biopharmaceutics and Clinical Pharmacokinetics, $4^{\text {th }}$. Lea and Febiger, Philadelphia, pp. 87-91

DUNNETT, CW, GOLDSMITH, CH 1994: When and how to do multiple comparisons. In Statistics in the Pharmaceutical Industry, vol. 140, Eds. C. R. Buncher and. J-Y. Tsay, Marcel Dekker, Inc., New York, pp. 481-511

JENSEN, J, GUGLER, R 1983: Single- and multiple-dose metronidazole kinetics. Clin Pharmacol Therap 34: 481-487

LOFT, S, DOSSING, M, POULSEN, HE, SONNE, J, OLESEN, K-L, SIMONSEN, K, ANDREASEN, PB 1986:Influence of dose and route of administration on disposition of metronidazole and its major metabolites. Europ J Clin Pharmacol 30: 467-473

MUSCAR, MN, PEDRAZZOLI, JR, J, MIRANDA, EL, FERRAZ, JG, HOFSTETTER, E, LEITE, G, MAGALHVES, AF, LEONARDI, S, De NUCCI, G 1995: Plasma hydrox-metronidazole/metronidazole ratio in patients with liver disease and in healthy volunteers. Brit J Clin Pharmacol 40: 477-480

NEFF-DAVIS, CA, DAVIS, LE, GILLETTE, EL 1981: Metronidazole: a method for its determination in biological fluids and its disposition kinetics in the dog. J Vet Pharmacol Therap 4: 121-127

PRESCOTT, JF, BAGGOT, DJ 1993: Miscellaneous antibiotics: Ionophores, nitrofurans, nitroimidazoles, rifampin and others. In Antimicrobial Therapy in Veterinary Medicine, $2^{\text {nd }}$ Ed, Iowa State University Press, Ames, pp. 263-292

ROWLAND, M, TOZAR, TN 1995a: Turnover concepts. In Clinical Pharmacokinetics; concepts and applications, $3^{\text {rd }}$ Ed. Williams and Wilkins, Philadelphia, pp. 424-442

ROWLAND, M, TOZAR, TN 1995b: Multiple dose regimens. In Clinical Pharmacokinetics; concepts and applications, $3^{\text {rd }}$ Ed. Williams and Wilkins, Philadelphia, pp. 83-105

SPECHT, TE, BROWN, MP, GRONWALL, RR, RIB, WJ, HOUSTON, AE 1992: Pharmacokinetics of metronidazole in body fluids and endometrial tissues of mares. Amer J Vet Res 53: 1807-1812

STAMPAUGH, JE, FEO, LG, MANTHEI, RW 1968: The isolation and identification of the urinary oxidative metabolites of metronidazole in man. J Pharmacol Exp Therap 161: 373-381

TU, YH, WANG, Y, ALLEN, LV JR., ALBERS, DD, GORGIN, MK 1990: Pharmacokinetics of metronidazole administered intravenously to male rats. Inter J Pharmac 61: 119-125 